\title{
Політичний міф, міфологізація сучасного суспільства за допомогою соціальних мереж
}

\author{
Рагімова А. Б., Національний авіаційний університет
}

Проаналізовано основні підходи науковців до визначення поняття «політичний міф» та запропоноване власне визначення даного поняття. На думку автора, політичний міф - це комплекс інструментів, які застосовуються із урахуванням людських слабкостей та емоційних переживань та спрямовані на досягнення особистих цілей представників політичного сектору держави у сфері реалізації політичних цілей або в контексті інформаційних війн. Охарактеризовано політичні рівні, на яких виникають та існують політичні міфи. 3'ясовано, що масова культура виникла не тільки як противага елітарній, а ще й створила свого споживача - усереднену й невибагливу масову людину, яка характеризується такими ознаками: кількісна перевага, територіальна неоднорідність людей, гетерогенність, анонімність безлічі індивідів, відсутність структурної організації, визнаного лідера і визначеної програми соціальних дій, схильність до навіювання. Визначено, що у сучасному суспільстві ЗМІ виконують низку функцій, важливими серед яких є: комунікативна, інформаційна, ретрансляційна, пропагандистська. Проаналізовано структуру вподобань українських громадян щодо вибору соціальних мереж та визначено, що у 2017 році українці надавали перевагу таким соціальним мережам, як Facebook (51.96\%), Twitter (32.05\%). Проаналізовано види політичних міфів: міф «про рятівника-месію», міф «про змову», міф «випробування долі», міф «про доброзичливе співтовариство». Охарактеризовано сучасні прояви політичної міфологізації сучасного суспільства за допомогою соціальних мереж.

Ключові слова: міф; політика; політичний міф; міфологізація політики; соціальні мережі; мас-медіа; засоби масової інформації

\section{The political myth, the mythologization of modern society through social networks}

\section{Ragimova A. B., National Aviation University}

To date there are a number of acute problems that are discussed by philosophers, political scientists, sociologists, psychologists, anthropologists, and cultural scientists. Among them, one can highlight the issue of political myths in modern society. Mythologization is not only the first and only form of social consciousness, but also a factor, shaping the socio-cultural space of the present and the future. With the help of this tool, the mentality of the people is formed and the historical background of the scenario of the future development of the state is laid. Society as a whole, and individuals, in particular, react to crises and threats, or using innovative ideas, or by resorting to old methods that have been successfully used to overcome previous crises.

The results of the study of the relationship between politics and the creation of myths are reflected in the scientific works of such authors as V. Andrushchenko, V. Bebik, M. Holovaty, V.Gorsky, A. Donchenko, M. Karmazin, Yu. Levenets, I. Kresin, V. Korolka, V.Matvienko, M. Mikhalchenko, M. Obushny, G. Pocheptsova, Yu. Romanenko, Z. Samchuk, Yu. Shapoval, F. Shulzhenko and others. Some aspects of myth-creation were studied by such authors as : O. Donchenko, Yu. Romanenko, O.Yatsunskaya, S. Kara-Murza, T. Rassadina, S. Lebedev, O. Makarova, D. Usov, P. Gurevich, E. Kassierer, K. Hübner, R. Bart, D. Dadayan, O. Zazdravnova, Yu.Levenets, G. Pochetsov, T. Paniotova, Yu. Shajgorodsky and others. However, the author's opinion is that, the theoretical aspects of the issue under study require a generalization of concepts for a more comprehensive understanding of the mechanisms of its implementation in modern society.

The main purpose of writing this article is to generalize the theoretical aspects of the political mythologization of modern society through social networks.

The article analyzes the main approaches of scientists to the definition of the concept of «political myth» and proposes the actual definition of this concept. In article it's researched that the political myth is a set of tools that are applied taking into account human weaknesses and emotional experiences and aimed at achieving the personal goals of representatives of the political sector of the state in the realization of political ambitions or in the context of information wars. In the article the political levels, in which political myths arise and exist are characterized. First level is the theoretical one, which is connected with the development and functioning in the minds of individuals fundamental social science knowledge and values, which are the basis of state ideology. The second one is the propaganda level, which is associated with the development and introduction of publicly available ideological knowledge and values that are acceptable for mass learning and assimilation of mass consciousness through the various mythological forms. It was discovered that mass culture arose not only as a counterweight to the elite one, but also to create its consumer - an average and unbecoming mass person, characterized by the following features as: the quantitative superiority; territorial heterogeneity of people; anonymity of many individuals; the absence of a structural organization, recognized leader and defined program of social action; inclination to suggestion. It is determined that in modern society, the mass media perform a number of 
functions, the most important of which are: communicative (observing events and forming public opinion in relation to their essence); informative (collecting, editing, commenting and disseminating information); relaying (reproduction of a certain way of life with an appropriate set of political, spiritual, social values); propaganda (very often is masked). The structure of preferences of Ukrainian citizens regarding the choice of social networks is analyzed. And it was determined that in 2017 Ukrainians preferred social networks such as Facebook (51.96\%), Twitter (32.05\%). The types of political myths are also analyzed: myth «about the rescuer-messiah», myth «about conspiracy», myth of «trial of destiny», myth of «the benevolent community». The modern manifestations of the political mythologization of modern society with the help of social networks are characterized.

Keywords: myth; politics; political myth; political mythology; social networks; mass media

\title{
Политический миф, мифологизация современного обществапосредством социальных сетей
}

\author{
Рагимова А. Б., Национальный авиационный университет
}

Проанализированы основные подходы ученых к определению понятия «политический миф» и предложено собственное определение данного понятия. По мнению автора, политический миф - это комплекс инструментов, которые применяются с учетом человеческих слабостей и эмоциональных переживаний и направлены на достижение личных целей представителей политического сектора государства в сфере реализации политических целей или в контексте информационных войн. Охарактеризованы политические уровни, на которых возникают и существуют политические мифы. Установлено, что массовая культура возникла не только как противовес элитарной, но и создала своего потребителя - усредненного и непритязательного массового человека, который характеризуется следующими признаками: количественное преобладание, территориальная неоднородность людей, гетерогенность, анонимность множества индивидов, отсутствие структурной организации, признанного лидера и определенной программы социальных действий, склонность к внушению. Определено, что в современном обществе СМИ выполняют ряд функций, важными из которых являются: коммуникативная, информационная, ретрансляционная, пропагандистская. Проанализирована структура предпочтений украинских граждан по выбору социальных сетей и определено, что в 2017 году украинцы предпочтение отдавали таким социальным сетям, как Facebook (51.96\%), Twitter (32.05\%). Проанализированы виды политических мифов: миф «о спасителе-мессии», миф «о заговоре», миф «испытания судьбы», миф «о доброжелательном сообществе». Охарактеризованы современные проявления политической мифологизации современного общества с помощью социальных сетей.

Ключевые слова: миф; политика; политический миф; мифологизация политики; социальные сети; СМИ; средства массовой информации

\section{Постановка проблеми.}

$\mathrm{H}$ а сьогоднішній день існує низка гострих проблем, які обговорюють філософи, політологи, соціологи, психологи, антропологи, культурологи. Серед них можна виділити питання про політичні міфи у сучасному суспільстві. Міфологізація є не тільки першою та єдиною формою суспільної свідомості, а й чинником, який формує соціокультурний простір сучасності та майбутнього. За допомогою даного інструменту формується ментальність народу та закладаються історичні передумови сценарію майбутнього розвитку держави. Суспільство загалом та особистості зокрема реагують на кризові явища та загрози або використовуючи інноваційні ідеї, або звертаючись до старих методів, які успішно застосовувались у подоланні попередніх криз.

\section{Аналіз останніх публікацій.}

Результати дослідження співвідношення політики та створення міфів відбиваються у наукових працях таких авторів: В. Андрущенка, В. Бебика, М. Головатого, В. Горського, О. Донченка, М. Кармазіної, Ю. Левенця, І. Кресіної, В. Королька, В. Матвієнка, М. Михальченка, М.
Обушного, Г. Почепцова, Ю. Романенка, 3. Самчука, Ю. Шаповала, Ф. Шульженка та ін. Окремі аспекти міфотворчості досліджували такі автори, як: О. Донченко, Ю. Романенко, О. Яцунська, С. Кара-Мурза, Т. Рассадіна, С. Лебедєв, О. Макарова, Д. Усов, П. Гуревич, Е. Кассірер, К. Хюбнер, Р. Барт, Д. Дадаян, О. Заздравнова, Ю. Левенець, Г. Почепцов, Т. Паніотова, Ю. Шайгородський та ін. Однак, на мою думку, теоретичні аспекти досліджуваного питання потребують узагальнення понять для більш комплексного уявлення про механізми його реалізації у сучасному суспільстві.

\section{Формулювання цілей статті.}

Метою даної статті є узагальнення теоретичних аспектів політичної міфологізації сучасного суспільства за допомогою соціальних мереж.

Виклад основного матеріалу дослідження.

Сучасні умови розвитку держави характеризуються тим, що в суспільстві втрачається здатність його членів до вирішення проблем раціональним шляхом. Міфи є впливовим засобом політичної зброї, здатної підкорити, згрупувати й спрямувати людей у стратегічному напрямку. Тому не дивно, 
що політики використовують цю зброю 3 метою політичних маніпуляцій. Розглянемо основні підходи науковців до табл. 1). визначення поняття «політичний міф» для більш глибокого розуміння досліджуваного явища (див.

Таблиия 1. Основні підходи науковців до визначення поняття «політичний міф»*

\begin{tabular}{|c|c|c|}
\hline № & Автор & Трактування \\
\hline 1 & Н. Пробийголова [7] & $\begin{array}{l}\text { інструмент, який цілком усвідомлено задіяний в } \\
\text { інформаційних війнах і оснований на знанні людської } \\
\text { природи }\end{array}$ \\
\hline 2 & Ю. Шайгородський [11] & $\begin{array}{l}\text { цілісне, спрощене, переважно ірраціональне відображення } \\
\text { в індивідуальній та масовій свідомості політичної } \\
\text { реальності й основних суспільних цінностей, своєрідний } \\
\text { символічний засіб їхньої інтерпретації, моделювання світу } \\
\text { і соціального життя; інструмент реалізації конкретних } \\
\text { політичних завдань - боротьби за владу, іiі легітимації, } \\
\text { утвердження нової політичної ідеології тощо }\end{array}$ \\
\hline 3 & Н. Карпова [2] & $\begin{array}{l}\text { генетичний елемент політичної культури, який являє } \\
\text { собою систему історично сформованих образів, в яких } \\
\text { полягає колективна пам'ять народу, що зберігає в собі } \\
\text { суспільно-політичний досвід }\end{array}$ \\
\hline 4 & А. Цуладзе [10] & $\begin{array}{l}\text { міф, що використовується для реалізації політичних цілей: } \\
\text { боротьба за владу, легітимізація влади, здійснення } \\
\text { політичного панування, також зазначається, що міф } \\
\text { дозволяє нам здійснювати комунікацію із зовнішнім світом }\end{array}$ \\
\hline 5 & Н. Лютко [4] & $\begin{array}{l}\text { механізм духовно-морального виміру політики, що } \\
\text { викликає емоційні переживання, які мотивують політичну } \\
\text { поведінку, та спираючись на раціонально затверджений } \\
\text { смисловий стрижень, пристосовують міф до політичних } \\
\text { технологій }\end{array}$ \\
\hline
\end{tabular}

*- складено автором за матеріалами $[2 ; 4 ; 7 ; 10 ; 11]$.

Таким чином, можемо зробити висновок, що підходи науковців до трактування поняття «політичний міф» досить різняться між собою. Зокрема, Н. Пробийголова вважає, що політичний міф - інструмент, який цілком усвідомлено задіяний в інформаційних війнах і оснований на знанні людської природи. Політика стає раціональною формою використання ірраціональної сутності мас, що свої інтереси готові усвідомлювати тільки в яскравих і містичних образах. Тому керування масою спирається на знання архетипу, найдавніших психічних установок, основних емоційних станів [7].

На думку Ю. Шайгородського, політичний міф визначається як цілісне, спрощене, переваж- но ірраціональне відображення в індивідуальній і масовій свідомості політичної реальності та основних суспільних цінностей, своєрідний символічний засіб їхньої інтерпретації, моделювання світу і соціального життя; інструмент реалізації конкретних політичних завдань - боротьби за владу, іiі легітимації, утвердження нової політичної ідеології тощо [11].

Тоді як Н. Карпова зауважує, що політичний міф - це генетичний елемент політичної культури, який являє собою систему історично сформованих образів, в яких полягає колективна пам'ять народу, що зберігає в собі суспільно-політичний досвід [2].

На думку російського дослідника А. Цуладзе, 
політичний міф є міфом, що використовується для реалізації політичних цілей: боротьба за владу, легітимація влади, здійснення політичного панування, і зазначає, що міф дозволяє нам здійснювати комунікацію із зовнішнім світом [10].

На думку Н. Лютко, політичний міф виступає як механізм духовно-морального виміру політики, викликаючи емоційні переживання, які мотивують політичну поведінку та, спираючись на раціонально затверджений смисловий стрижень, пристосовують міф до політичних технологій [4].

Проаналізувавши основні підходи до визначення даного поняття, можемо запропонувати власне визначення. Політичний міф - це комплекс інструментів, які застосовуються 3 урахуванням людських слабкостей та емоційних переживань та спрямовані на досягнення особистих цілей представників політичного сектору держави у сфері реалізації політичних цілей або в контексті інформаційних війн.

Як влучно підкреслює А. Мороз, зрозуміти чи об' єктивно пізнати природу політичного міфу нереально, адже він переважно грунтується на вірі та стереотипах. Однак це необов'язково означає, що явище політичної міфології в політичному процесі має суто негативне значення. Однією 3 важливих позитивних якостей політичних міфів $€$ здатність об’єднувати людей навколо певної ідеї. Політична міфологія покликана формувати ілюзії серед населення [6].

Міфотворчість була і залишається невід'ємною складовою політичних процесів. Технологія творення міфів (як мистецтво, майстерність, метод перетворення даного у необхідне) грунтується на розумінні ступеня впливу міфу на свідомість та його особливостях, зокрема на тому, що він спирається і оперує не дійсністю, а психологічними станами, очікуваннями людей [11]. Політична система $є$ тим середовищем, де народжується та розвивається безліч міфів. Україна, як і будь-яка інша держава, характеризується високою здатність до міфотворчості.

I тут не можна не погодитися з С. Макаренко, яка зазначає, що політичні міфи виникають та існують на декількох рівнях [5]:

1. По-перше, на теоретичному рівні, пов'язаному з виробленням та функціонуванням у свідомості особистостей фундаментальних суспільствознавчих знань та цінностей, які $є$ основою державної ідеології. Тобто міфи, які створюються на державному рівні. Об'єктом такого державного міфу є державне буття суспільства у всій багатоманітності його проявів - політика, право, економіка, соціальна сфера, релігія.

2. По-друге, на пропагандистському рівні, пов'язаному 3 розробкою та запровадженням загальнодоступних ідеологічних знань та цінностей, які прийнятні для масового вивчення та засвоєння масовою свідомістю за допомогою різних міфологічних форм. Тобто формування та функціонування міфів на рівні повсякденних ідеологічних уявлень та поглядів.

Будь-яка політична культура не може існувати без функціонування масової культури великої спільноти людей, що перебувають у єдиному культурному просторі, які здатні частково формувати та розповсюджувати певну інформацію. Ефективність впливу поширюваної інформації не потребує високого інтелектуального та духовного рівня від того, хто їі сприймає.

Як зазначає О. Гойман, масова культура виникла не тільки як противага елітарній, а ще й створила свого споживача - усереднену й невибагливу масову людину, яка характеризується такими ознаками [1]:

1) кількісна перевага;

2) територіальна неоднорідність людей;

3) гетерогенність;

4) анонімність безлічі індивідів;

5) відсутність структурної організації, визнаного лідера i

визначеної програми соціальних дій;

6) схильність до навіювання.

3 огляду на це у сучасному суспільстві 3МІ виконують низку функцій, важливими серед яких $є$ [5]:

- комунікативна (спостереження за подіями i формування суспільної думки стосовно їхньої сутності);

- інформаційна (збирання, редагування, коментування та поширення інформації);

- $\quad$ ретрансляційна (відтворення певного способу життя з відповідним набором політичних, духовних, соціальних цінностей);

- пропагандистська (яка іноді маскується).

Реалізовуючи зазначені функції, засоби масової інформації мають змогу впливати на різні сфери життя суспільства, на особливості соціально-психологічного та духовно-культурного розвитку кожної особистості. Це проявляється у тому, що просування нової інформації по каналах засобів масової інформації відповідним чином закріплює у свідомості членів суспільства сукупність нових ціннісних орієнтацій та установок.

Одним із важливих інструментів масової комунікації виступають соціальні мережі. Вони утворюють кільце зворотного зв' язку між індивідуумами та соціальними групами, між політичною системою та суспільством, а також між елементами політичної системи. Забезпечуючи суспільний дискурс, вони виступають необхідним фактором розвитку демократії. Швидкісне, мультимедійне спілкування стає можливим завдяки існуванню 
багатьох соціальних мереж: «Facebook» (кількість користувачів понад 1,2 млрд. на 2013 р.), «Twitter» (500 млн. зареєстрованих користувачів), та ін. Отже, глобальне онлайн-середовище розширюєть- ся кожного дня завдяки залученню до нього нових користувачів [9]. На рис. 1 розглянемо структуру вподобань українських громадян щодо вибору соціальних мереж.

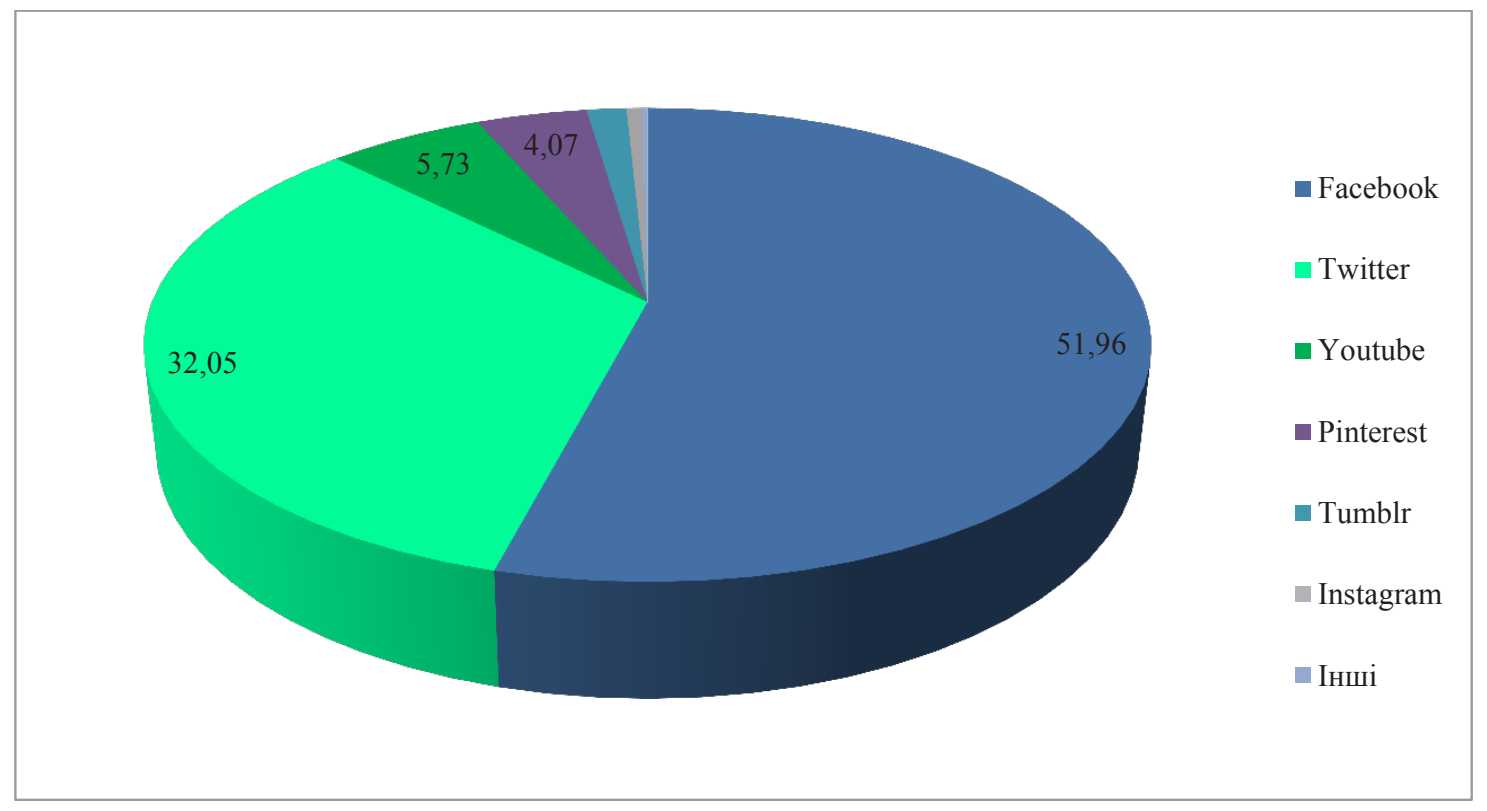

Puc.1. Структура користування соціальними мережами у 2017 році*

*- розроблено автором на основі [8].

На рис. 1 яскраво видно, що у 2017 році українці надавали перевагу таким соціальним мережам, як Facebook (51.96\%), Twitter (32.05\%). Меншу частку займають такі медіа, як Youtube (5.73\%) та Pinterest (4.07\%). Зовсім незначну частку соціальних мереж займають Instagram, Tumblr та ін.

Використання соціальних мереж як засобу спілкування 3 аудиторією є надзвичайно важливим інструментом для налагодження політичної комунікації, а зважаючи на умови соціально-економічного та політичного стану у державі, соціальні мережі $є$ ефективними засобами активізації громадянського суспільства та забезпечення участі громади у державотворчих процесах.

Н. Пробийголова [7] зауважує, що за чудово виготовленим рекламним іміджем члену суспільства буває складно розрізнити справжні ділові i моральні якості кандидатів, визначити їхні політичні позиції. Такого роду рекламно-маніпулятивна діяльність перетворює вибір громадян замість вільного свідомого рішення на формальний акт, заздалегідь запрограмований фахівцями 3 формування масової свідомості. Автор запропонував такі види міфів:

1. Міф «про рятівника-месію». Кандидат, навколо якого створюється цей міф, сприймається як людина, що, за умови приходу її до влади, зможе вивести країну $з$ кризи або складного становища. Цей міф грунтується на архетипі «героя». Як приклад в передвиборчій ситуації в Україні можна навести обігрування постаті Віктора Ющенка як кандидата в Президенти.

2. Міф «про змову» достатньо сильно зафіксований у масовій свідомості. Експлуатація цього міфу в масовій свідомості у період передвиборчих перегонів здійснюється досить часто та у різних формах, що можуть мати не завжди соціально позитивну спрямованість. Грунтується цей міф на архетиповій конструкції відносин «свої-чужі», «друг-ворог».

3. Міф «випробування долі»- наочно закріплений у народних прислів’ях: «За одного битого двох небитих дають», «Пройшов крізь вогонь, воду та мідні труби» тощо. Як правило, завдяки випробуванню людина набуває загартованості, глибоких людських якостей, значного особистісного досвіду. Саме на цьому акцентується увага при агітації за певного кандидата - його попередній досвід та досягнення мають стати запорукою успіхів у майбутній політичній діяльності.

4. Міф «про доброзичливе співтовариство» - експлуатує переконання, що завжди є певне добре співтовариство, «інші люди такі ж добрі, як я сам», «нам хтось допоможе». Тобто формування образу доброго героя, про значимість взаємовиручки й взаємодопомоги. Ця категорія міфів має дуже давню історію (казки слов'ян, скандинавів та інших народів про добрих героїв). Використо- 
вується переконання в тому, що надана допомога повертається ще більшою мірою від інших. У цілому перелік сталих міфів у соціокультурному середовищі дуже великий.

Серед сучасних політичних міфів - міф про «реформи», суспільство рівних можливостей, європейський вибір та інтеграцію в Свропу, «єдину Україну» і т. ін. В сучасних умовах Україна балансує між пошуками шляхів свого «відродження» та «європейським вибором», що стає ще одним міфом. У масовій свідомості європейський вибір набуває міфічного образу раю та безпроблемного життя («євроремонт», «євровікна», «безвізовий режим» тощо) [3].

У політичній міфологізації сучасного суспільства за допомогою соціальних мереж використовуються такі особливості міфології, як здатність до перекручення світогляду та зачарування свідомості. Зачарування свідомості повинно задовольняти потребу людини в надзмісті тих ідей, які вкладаються у політичній рекламі. Це досягається за допомогою таких прийомів: посилення почуттів, внаслідок яких людина може збільшити обсяг своїх ресурсів; символізація, коли людям чи подіям надається символічний зміст, помилкове злиття політичних об'єктів або їхнього змістовного навантаження. Духовне злиття з будь-яким політичним об'єктом чи суб'єктом (людиною, політичним лідером) задовольняє потребу в афіліації [11].
На сьогоднішній день прикладами політичних міфів у соціальних мережах є міфи, приховані у символах (мандарини під час помаранчевої революціï), метафорах (у вигляді «капіталізму з людським обличчям»), піснях, притчах або анекдотах, у публікаціях, які відображають сукупність певних поглядів та ставлення до духовних цінностей людей. На сучасному етапі елементи міфологізації також можуть виражатися у певних образах, гаслах, рекламних слоганах, афоризмах, чутках, думках та новинах, які поширюють політики у власних акаунтах соціальних мереж.

\section{Висновки 3 дослідження.}

Підсумовуючи усе вищезазначене, можемо зробити висновок, що на сьогоднішній день у медіа-просторі створені сприятливі умови, які надають можливість застосовувати міфологічні технології під час формування політичної пропаганди. Політичні міфи відбивають ціннісні орієнтири поточного культурного середовища громадян. Саме до використання міфів тяжіють політики при виборі способів структурування інформації у соціальних мережах, які функціонують за законами ЗМІ. Політична реклама в соціальних мережах визначає комплекс соціально-культурних норм, апелюючи до колективного досвіду та моделюючи систему цінностей суспільства, що у свою чергу сприяє політичним діячам у досягненні їхніх цілей.

\section{БІБІЛІОГРАФІЧНІ ПОСИЛАННЯ}

1. Гойман О. О. Міфологічний аспект реклами у масовій культурі / О. О. Гойман // Дні науки філософського факультету. - 2014. - С. 30-33.

2. Карпова Н. В. Политический миф в системе политико-культурной генетики / Н. В. Карпова // ХХ Международная конференция памяти профессора Л. Н. Когана «Культура, личность, общество в современном мире: Методология, опыт эмпирического исследования», 16-18 марта 2017 г., Екатеринбург. - Екатеринбург: УрФУ, 2017. C. 1986-1995.

3. Коробанова О. Л. Міфи і реальність у Політичній свідомості молоді / О. Л. Коробанова // Вісник ОНУ ім. I. I. Мечникова. Серія: Психологія. - 2016. - Т. 21. - № 1. - С. 125-136.

4. Лютко Н. В. Міфологізація політичної реклами / Н.В. Лютко // Наукові праці Чорноморського державного університету імені Петра Могили комплексу «Києво-Могилянська академія». Серія: Політологія. - 2014. - Т. 228. - № 216. - С. 105-108.

5. Макаренко С. Міф як засіб масової комунікації / С. Макаренко // Міжнародні відносини: історія та сучасність. - Режим доступу: http://www.americanstudies.history.knu.ua/wp-content/uploads/2017/ 11/24-Makarenko.pdf

6. Мороз А. Міфологізація політичних цінностей у контексті президентської кампанії 2010 року / А. Мороз. - Режим доступу: http://www.viche.info/journal/1836

7. Пробийголова Н. В. Міф як засіб політичного маніпулювання в процесі проведення виборів // Науковий вісник Ужгородського університету. Серія: Політологія, Соціологія, Філософія. - № 14. - Ужгород: Говерла, 2010. C. 41-44

8. Самые популярные социальные сети в странах СНГ и мире. - Режим доступа: https://marketer.ua/top-socialmedia-2017.

9. Сахань О. М. Про використання соціальних мереж інтернету як засобу створення іміджу політичної влади в Україні / О. М. Сахань // Вісник Національної юридичної академії України імені Ярослава Мудрого. Серія: Філософія, філософія права, політологія, соціологія. - 2014. - № 2. - С. 143-154.

10. Цуладзе А. М. Политическая мифология / А. М. Цуладзе. - М.: Изд-во «Эксмо», 2003. - 384 с.

11. Шайгородський Ю. Політичний міф як інструмент дослідження політики / Ю. Шайгородський // Сучасна українська політика. Політики і політологи про неї, 2010. - № 21. - С. 32-38 


\section{REFERENCES}

1. Hojman, O.O. (2014). Mifolohichnyi aspekt reklamy u masovii kulturi [Mythological aspect of advertising in mass culture]. Dni nauky filosofs' koho fakul'tetu, (pp. 30-33) [in Ukrainian].

2. Karpova, N.V. (2017). Polytycheskyi myf v systeme polytyko-kulturnoi henetyky [Political myth in the system of political and cultural genetics]. XX Mezhdunarodnaia konferentsyia pamiaty professora L. N. Kohana «Kul 'tura, lychnost', obschestvo v sovremennom myre: Metodolohyia, opyt empyrycheskoho yssledovanyia» - XX International Conference in memory of Professor LN Kogan «Culture, Personality, Society in the Modern World: Methodology, Experience of Empirical Research». Ekaterynburh: UrFU, 1986-1995 [in Russian].

3. Korobanova, O.L. (2016). Mify i realnist u Politychnii svidomosti molodi [Myths and Reality in the Youth Consciousness]. Visnyk ONU im. I. I. Mechnykova. Psykholohiia, 1, 125-136 [in Ukrainian].

4. Liutko, N.V. (2014). Mifolohizatsiia politychnoi reklamy [Mythologization of political advertising]. Naukovi pratsi Chornomors'koho derzhavnoho universytetu imeni Petra Mohyly kompleksu Kyievo-Mohylians'ka akademiia. Politolohiia, 216, 105-108 [in Ukrainian].

5. Makarenko, Ie. Mifyak zasib masovoi komunikatsii [Myth as a means of mass communication]. Mizhnarodni vidnosyny: istoriia ta suchasnist. Retrieved from: www.americanstudies.history. knu.ua/wp-content/uploads/2017/11/24-Makarenko. pdf [in Ukrainian].

6. Moroz, A. Mifolohizatsiia politychnykh tsinnostei u konteksti prezydentskoi kampanii 2010 roku [Mythologization of political values in the context of the 2010 presidential campaign]. Retrieved from: http://www.viche.info/journal/1836 [in Ukrainian].

7. Probyjholova, N.V. (2010). Mif yak zasib politychnoho manipuliuvannia v protsesi provedennia vyboriv [Myth as a means of political manipulation in the course of elections]. Naukovyj visnyk Uzhhorods'koho universytetu. Politolohiia, Sotsiolohiia, Filosofiia., 14, 41-44 [in Ukrainian].

8. The most popular social networks in the CIS countries and the world. Retrieved from: https://marketer.ua/top-socialmedia-2017 [in Russian].

9. Sakhan', O.M. (2014). Pro vykorystannia sotsialnykh merezh internetu yak zasobu stvorennia imidzhu politychnoi vlady v Ukraini [About the use of social networks of the Internet as a means of creating an image of political power in Ukraine]. Visnyk Natsional'noi iurydychnoi akademii Ukrainy imeni Iaroslava Mudroho. Filosofiia, filosofiia prava, politolohiia, sotsiolohiia, 2, 143-154 [in Ukrainian].

10. Tsuladze, A.M. Polytycheskaia myfolohyia [Political Mythology]. Moscow: Yzd-vo «Eksmo» [in Russian].

11. Chajhorods'kyj, Iu. (2010). Politychnyi mif yak instrument doslidzhennia polityky [Political myth as a policy research tool]. Suchasna ukrains 'ka polityka. Polityky i politolohy pro nei, 21, 32-38 [in Ukrainian].

\section{Рагімова Анастасія Борисівна}

Кандидат політичних наук, доцент

Національний авіаційний університет

02000, м. Київ, проспект Космонавта Комарова, 1

\section{Ragimova Anastasiia B.}

$\mathrm{PhD}$ in Political sciences, Associate Professor

National Aviation University

1, Kosmonavta Komarova Ave., 02000, Kyiv, Ukraine

Email: anastasiya.ragimova@gmail.com

Цитування: Рагімова А. Б. Політичний міф, міфологізація сучасного суспільства за допомогою соціальних мереж / А. Б. Рагімова // Науково-теоретичний альманах «Грані». - 2018. T. 21. - № 4. - C. 18-24.

Citation: Ragimova, A.B. (2018). Politychnyi mif, mifolohizatsiia suchasnoho suspilstva za dopomohoiu sotsialnykh merezh [The political myth, the mythologization of modern society through social networks]. Scientific and theoretical almanac «Grani», 21(4), 18-24. 